competition among students in Forestry, Engineering and Architecture on behalf of the F.P.R.S. These were as follows:

\title{
Engineering and Architecture Subjects
}

Etude de la charpente en bois lamellé pour la construction d'une église à Ville Lasalle, Quebec. J. G. Trudeau, Ecole Polytechnique, Montreal. This paper prepared in French with an English summary. Award- $\$ 50.00$.

Design and Performance of the Suction Press on Modern Newsprint Machines. J. W. Smith, Queen's University, Kingston. Award- $\$ 50.00$.

Design of a Prefabricated Plywood Industrial Building. J. D. Hodd and R. F. White. N.S. Technical College, Halifax. Award- $\$ 25.00$.

Forestry Subjects

Bolts-A Factor in the Utilization of Low Quality Hardwoods. J. Johnston, University of Toronto, Toronto. Award- $\$ 25.00$.

\section{ERRATUM}

The volume formula at the bottom of Page 366 (Vol. 31, No. 4) of the December 1955 Forestry Chronicle should read:

Volume $=58.06($ tree height $)+33.46$ (crown diameter $)+40.57$ (crown density) - 2653.

\section{B.C. Registered Foresters}

The Council of the Association of British Columbia Foresters announces that the following candidates have completed the requirements and are now registered to practise forestry under the provisions of the B.C. Foresters Act: Maurice J. Ayers, H. J. Hodgins (Victoria) Ltd., Victoria; Kenneth G. Fensom, Dominion Forest Prod. Lab., U.B.C. Campus, Vancouver; Jack L. Robinson, B.C. Forest Service, Kamloops; Stanley M. Lockard, Vancouver; Peter E. Robson, B.C. Forest Service, Kamloops; John Walters, Research Forester, University Forest, Haney; Tollef Kilde, Rena, Norway; Ryszard Borzuchowski, B.C. Forest Service, Research Div., Victoria; Glen A. Patterson, Canadian Forest Products Ltd., Englewood; Donald T. Grant, B.C. Forest Service, Prince George; Nicholas Novak, Northern Plywoods Ltd., via Vancouver; William V. Lowry, Alaska Pine \& Cellulose Ltd., Vancouver; John F. Joyce, B.C. Forest Service, Nelson; G. G. Anthony Hilliard, Boundary Sawmills Ltd., Midway.

\section{Woodlands Research Director Appointed}

The appointment of Lowell Besley as Chairman of the woodlands research department of the Pulp and Paper Research Institute of Canada in Montreal was announced recently by Dr. Lincoln R. Thiesmeyer, president of the Institute. This appointment will take effect July 1. Mr. Besley was Dean of the Faculty of Forestry of the University of British Columbia. He has served as a director of the Canadian Institute of Forestry and chairman of its Vancouver section; as a director of the Canadian Forestry Association; and as vice-president of the Association of B.C. Foresters. He was born in Baltimore and educated at Cornell University and at Yale University where he received a Master of Forestry degree with distinction in 1931. He has been executivedirector of the American Forestry Association since July 1953. 